\title{
Rodent Macrophage Select Vin Blank Together with Vin Rouge According to SO Level in Situ
}

\author{
Nobuo Yamaguchi1,2, Keiko Matsuba², Kazuhiro Okamoto3, Takanao Ueyama4, \\ Yoshiichiroh Matsuba ${ }^{2}$, Katsuko Okuzumi ${ }^{5}$, Ikkan Watanabe', Takashi Takahashi ${ }^{5}$ \\ ${ }^{1}$ Department of Fundamental Research for CAM, Kanazawa Medical University, Uchinada, Japan \\ ${ }^{2}$ Ishikawa Natural Medicinal Products Research Center, Kanazawa, Japan \\ ${ }^{3}$ Graduate School of Medical Science, Kanazawa University, Kanazawa, Japan \\ ${ }^{4}$ Department of Medicine II, Kansai Medical University, Osaka, Japan \\ ${ }^{5}$ Laboratories of Infectious Diseases, Graduate School of Infection Control Sciences, Kitasato University, \\ Tokyo, Japan \\ Email: serumaya@kanazawa-med.ac.jp
}

Received 1 September 2014; revised 1 October 2014; accepted 1 November 2014

Copyright @ 2014 by authors and Scientific Research Publishing Inc.

This work is licensed under the Creative Commons Attribution International License (CC BY).

http://creativecommons.org/licenses/by/4.0/

(c) (i) Open Access

\begin{abstract}
Phagocytic cells are known as multi potent activities for its ontogenical and phylogenetical aspect. One of the strike actions is super oxide anion known as critical role of the cell when microorganisms invade inside the cytoplasm. This agent sometimes triggered as a serious factor in the site of inflammation. There are many papers which concerned newly accessed anti-oxidative substances. However, many reports only focused on the molecular basis in vitro, suggesting vin rouge for their rich content of polyphonol rather than vin blank with a French paradox. We had been suggested that the key factor for oxidative stress needs to be discussed first for immunological standpoint, such as in phagocytic cell in situ. With this assay system in rodent macrophage, So level was about the same for both groups administered vin blank as well as vin rouge.
\end{abstract}

\section{Keywords}

Super Oxide Anion, Anti-Oxidant Sample, Neutrophyl, Macrophage, Vin Blank, Vin Rouge, In Situ Estimation

\section{Introduction}

A phagocytic cell is famous for its mobile activity as the scavenger in the front of innate and adoptive immune

How to cite this paper: Yamaguchi, N., Matsuba, K., Okamoto, K., Ueyama, T., Matsuba, Y., Okuzumi, K., Watanabe, I. and Takahashi, T. (2014) Rodent Macrophage Select Vin Blank Together with Vin Rouge According to SO Level in Situ. Open Journal of Rheumatology and Autoimmune Diseases, 4, 240-247. http://dx.doi.org/10.4236/ojra.2014.44033 
system in mammals [1]-[5]. In a lower animal, even in invertebrate one, the phagocytic cell is essential for surviving a conventional circumstance [6]-[10]. In such cell, super oxide anion had been known as critical role in a phagocytic cell when microorganisms invaded inside [11]-[14]. But, this anion is not always necessary in a clean environment such as in the developed country. Moreover, this agent sometimes triggered as serious factor in the site of inflammation. There are many papers which concerned newly found anti-oxidants [15]-[26]. However, many reports only discussed about the molecular bases of mechanism in vitro/in test tube, and how oxidative stress damaged the human tissue. The key factor for oxidative stress has to be discused first for immunological standpoint, and with so-called armed reduction treaty. In other words, a minimum armed force is necessary for an invasion by outer or inner irregular cells. Many reports already reported that vin rouge reveals antioxidative effect but not vin blank. For the above standpoint on the ex vivo system by phagocytic cell, it is necessary to review the anti-oxidative effect of wine. So we tried to estimate anti-oxidative activity directory by employing peritoneal murine macrophage. The purpose of this study is to establish a conventional method which is useful for evaluating the antioxidant activity directory with host cell, macrophage. Oxidative stress is an important process that occurs in vivo during aging and is considered one of the main causes of molecular damage to cellular and tissue structures. These changes can gradually accumulate in the original biological structures during aging.

With aging, there is an increase of oxidative stress due to an imbalance between the oxidant production and the antioxidant levels. Since immunological cell functions are specially linked to free radical generation, the oxidant and antioxidant balance is essential for these cells. Although low levels of anti-oxidants bring armless status of a decreased in immune system, high levels of anti-oxidants could damage the tissues [27]-[34]. So ideal system was a regulation of daily status of immunological condition by phagocyte.

\section{Subjects and Methods}

\subsection{Animals}

Eight weeks old female C57BL/6NCrj were purchased from Sankyo Laboratory Service Corporation (Shizuoka, Japan). All mice were kept under SPF: specific pathogen-free conditions. The water and food were freely provided for each animal.

\subsection{Preparation of Peritoneal Macrophage}

\section{Subjects}

As for the basic medium, HEPES buffer (HEPES $17 \mathrm{mM}$, NaCl $120 \mathrm{mM}$, Glucose 5 mM, KCl 5 mM, CaCl 1 $\mathrm{mM}, \mathrm{MgCl}_{2} 1 \mathrm{mM}$ ) was prepared and sterilized by filtration. Phrbol 12-myristate 13-acetate (PMA, Sigma, USA) was diluted to $10-6 \mathrm{M}$ by dimethylsulfoxide (DMSO, Sigma, USA) and used as a stimulant for super oxide anion generation of murine peritoneal exudative cells. Cytochrome-C (Sigma, USA) was diluted to $1 \mathrm{mM}$ by HEPES buffer. Since cytochrome-C reduced by super oxide showed maximum absorbance at $550 \mathrm{~nm}$, we used cytochrome-C to measure the amount of super oxide anion generation through spectrophotometrical technique. Oyster Glycogen (type II, Sigma, USA) was diluted in the purified water (10\% w/v, Wako, Japan) and autoclaved at $120^{\circ} \mathrm{C}$ for 20 min. This solution was used for intraperitoneal injection to mice in order to induce peripheral neutrophils into the abdominal cavit.

In order to ensure if we really measured the amount of generated super oxide anion or not, we tried to add super oxide anion dismutase (SOD), famous enzyme for its anti-oxidative effect, into our experimental system. The result was as expected that the reduction of cytochrome-C was inhibited just after addition of SOD. This showed us that our experimental system could be used properly for measuring the amount of generated super oxide anion.

\subsection{Reagents}

As for the basic medium, HEPES buffer (HEPES $17 \mathrm{mM}$, NaCl $120 \mathrm{mM}$, Glucose $5 \mathrm{mM}, \mathrm{KCl} 5 \mathrm{mM}, \mathrm{CaCl}_{2} 1$ $\mathrm{mM}, \mathrm{MgCl}_{2} 1 \mathrm{mM}$ ) was prepared and sterilized by filtration. Phorbol 12-myristate 13-acetate (PMA, Sigma, USA) was diluted to $10^{-6} \mathrm{M}$ by dimethyl sulfoxide (DMSO, Sigma, USA) and used as a stimulant for super oxide anion generation of murine peritoneal exudative cells. Cytochrome-C; Cyt-C, (Sigma, USA) was diluted to $1 \mathrm{mM}$ by HEPES buffer. Since Cyt-C reduced by super oxide showed maximum absorbance at $550 \mathrm{~nm}$, we 
used Cyt-C to measure the amount of super oxide anion generation through spectrophotometrical technique.

Oyster Glycogen (type II, Sigma, USA) was diluted in the purified water (10\% w/v, Wako, Japan) and autoclaved at $120^{\circ} \mathrm{C}$ for $20 \mathrm{~min}$. This solution was used for intraperitoneal injection to mice in order to induce peripheral neutrophils into the abdominal cavity.

\subsection{Anti-Oxidative Sample}

Commercially available red and white wines were prepared and then aspirated overnight at ice cold bath in order to eliminate alcohol for mice. Followings are the commercially available wine for serve this experiment.

For Vin Blanc, "Château Cantemerle 1996 Haut Médoc 5ème Grand Cru Classé” was selected at Japanese wine delivery shop.

For Vin ouge, "Haut-Médoc Cru Bourgeois 2008 Château Bel Air” was selected as the same class of price at the delivery.

\subsection{A measuring the Amount of Super Oxide Anion Generated by Murine Peritoneal Macrophage Administered Vin Blanc or Vin Rouge}

Each wine sample was orally administered to mice $(200 \mathrm{mg} / \mathrm{kg})$ every day for one week. Then two $\mathrm{ml}$ of $10 \%$ oyster glycogen was injected intraperitonealy about 10 hours before the assay. A sufficient murine peritoneal exudate cells (PEC) were induced ten hours after the stimulation. Mice were euthanized by cervical dislocation, murine PEC suspension was centrifuged twice for 5 minutes at $1500 \mathrm{rpm}, 4^{\circ} \mathrm{C}$. Then PEC was prepared to $1 \times$ $10^{6}$ cells/ml of HEPES buffer. One hundred $\mu \mathrm{l}$ cytochrome-C and $10 \mu \mathrm{l}$ of PMA were added to the cell suspension and this was incubated for 20 minutes at $37^{\circ} \mathrm{C}$. The reaction mixture was then centrifuged for 10 minutes at $1500 \mathrm{rpm}, 4^{\circ} \mathrm{C}$. The OD of supernatant was measured at both $550 \mathrm{~nm}$ and $540 \mathrm{~nm}$, the amount of generated super oxide anion was shown in the formula; increased absorbance at $550 \mathrm{~nm}\left(\Delta \mathrm{A}_{550-540}\right) / 19.1 \times 10^{3} \mathrm{mmol} / \mathrm{ml}$.

In order to ensure if we really measured the amount of generated super oxide anion or not, we tried to add super oxide anion dismutase (SOD), famous enzyme for its anti-oxidative effect [21]-[23], into our experimental system. The result was as expected that the reduction of cytochrome-C was inhibited just after addition of SOD. This showed us that our experimental system could be used properly for measuring the amount of generated super oxide anion.

\subsection{Statistical Analysis}

The statistical comparisons between the groups for the test of significant difference were performed using paired t-test and Wilcoxon signed-ranks test. Further, the test of the correlation were performed a spearman's correlation coefficient by rank test. Data are expressed as means \pm standard error of mean (SE). A $P$ value $<0.05$ was considered to be statistically significant.

Data are expressed as means \pm standard deviations. The differences between HF-treated and non-treated conditions were compared using a one-tailed analysis of variance. A $P$ value $<0.05$ was considered to be statistically significant.

\section{Results}

\subsection{The Amount of Generated Super Oxide Anion and Chasing with SOD}

The peritoneal excaudate cells were collected 5 days after injection with oyster glycogen. The cell sample consisted with $92 \%$ of macrophages. The collected cell was treated by the method described in the Section 2.5. Before starting the main topics of this report, we try to check this reaction in Figure 1 depend on a super oxide anion. To confirm this SOD solution were mixed with the main cell suspension after concecutive minutes, post starting the reaction (Figure 1).

The amount of generated super oxide anion was calculated in the formula shown in the Section 2.5 (Table 1).

Figure 2, sufficient murine peritoneal exudate cells were induced ten hours after the stimulation. Mice were euthanized by cervical dislocation, murine peritoneal exudate cells (PEC) suspension was centrifuged twice for 5 minutes at $1500 \mathrm{rpm}, 4^{\circ} \mathrm{C}$. Then PEC was prepared to $1 \times 10^{6} \mathrm{cells} / \mathrm{ml}$ of HEPES buffer. One hundred $\mu \mathrm{l} \mathrm{cy-}$ tochrome-C and $10 \mu \mathrm{l}$ of PMA were added to the cell suspension and this was incubated for 20 minutes at $37^{\circ} \mathrm{C}$. 
Preparation of Peritoneal Exudate Cell
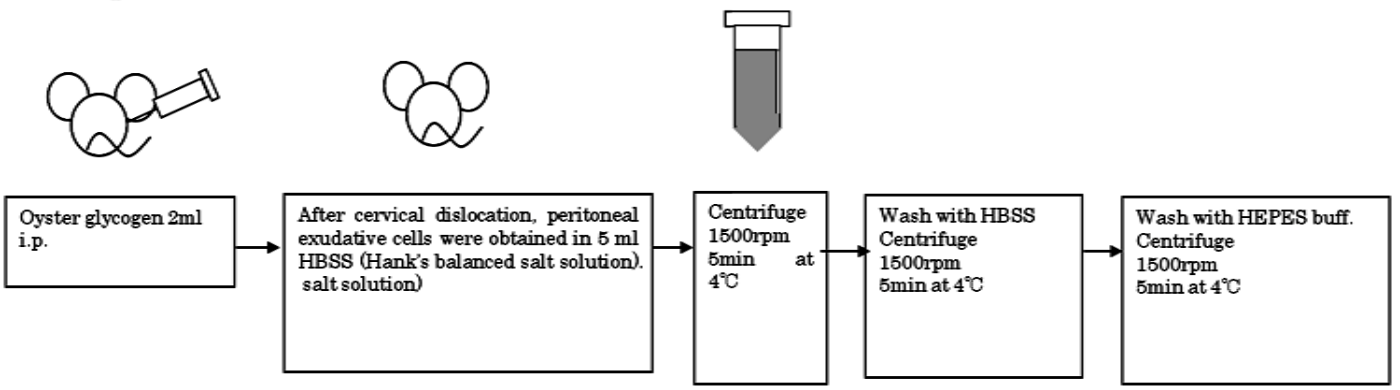

\section{Measurement of generated super oxide}

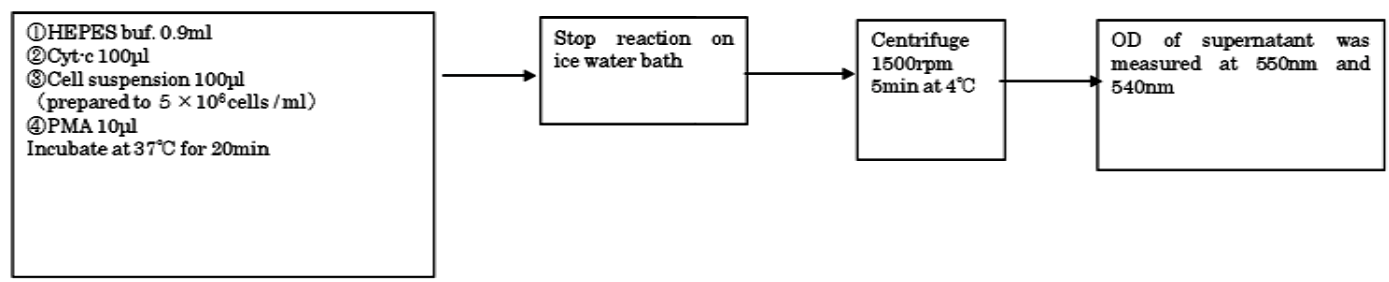

Figure 1. Experimental Design from Open Journal of Rheumatology and Autoimmune Diseases, 2014, 4, 13-21 with permission. A sufficient murine peritoneal exudate cell (PEC) was induced ten hours after the stimulation. Mice were euthanized by cervical dislocation, then murine PEC suspension was centrifuged twice for 5 minutes at $1500 \mathrm{rpm}, 4^{\circ} \mathrm{C}$. Then PEC was prepared to $1 \times 10^{6}$ cells/ml of HEPES buffer. One hundred $\mu$ cytochrome-C and $10 \mu \mathrm{l}$ of PMA were added to the cell suspension and this was incubated for 20 minutes at $37^{\circ} \mathrm{C}$. The reaction mixture was then centrifuged for 10 minutes at 1500 $\mathrm{rpm}, 4^{\circ} \mathrm{C}$. The OD of supernatant was measured at both $550 \mathrm{~nm}$ and $540 \mathrm{~nm}$, the amount of generated super oxide anion was shown in the formula; increased absorbance at $550 \mathrm{~nm}\left(\Delta \mathrm{A}_{550-540}\right) / 19.1 \times 10^{3} \mathrm{mmol} / \mathrm{ml}$. In order to ensure if we really measured the amount of generated super oxide anion or not, we tried to add super oxide anion dismutase (SOD), famous enzyme for its anti-oxidative effect, into our experimental system. The result was as expected that the reduction of cytochrome-C was inhibited just after addition of SOD. This showed us that our experimental system could be used properly for measuring the amount of generated super oxide anion.

Super oxide \& Elimination by SOD

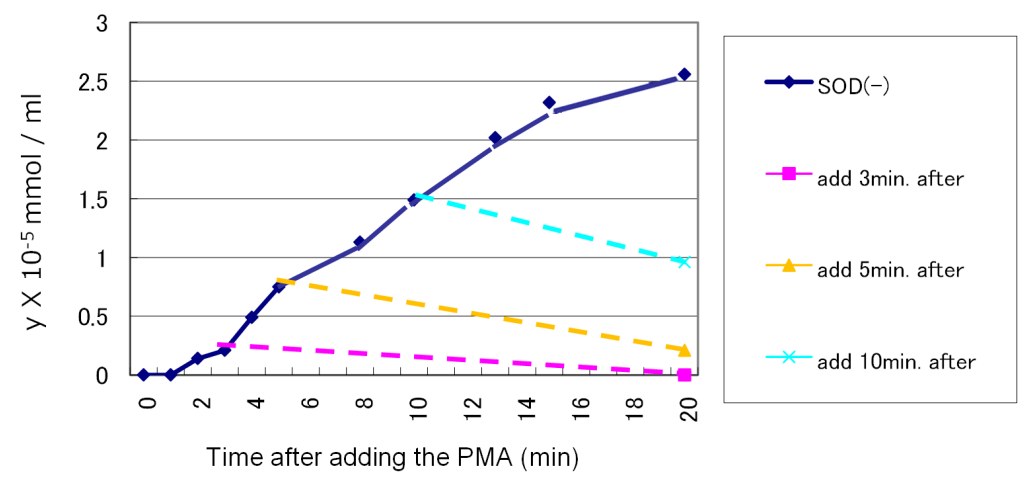

Figure 2. Chasing of super oxide activity by SOD. SOD was diluted to $1 \mathrm{mg} / \mathrm{ml}$ by HEPES buffer. Thirty $\mu 1$ of SOD was added to the reaction mixuture 3, 5 and 10 minutes after incubation, the reduction of cytochrome- $C$ was inhibited just after adding of SOD. Then PEC was prepared to $1 \times 10^{6}$ cells/ml of HEPES buffer. One hundred $\mu$ l cytochrome-C and $10 \mu 1$ of PMA were added to the cell suspension and this was incubated for 20 minutes at $37^{\circ} \mathrm{C}$. The reaction mixture was then centrifuged for 10 minutes at $1500 \mathrm{rpm}, 4^{\circ} \mathrm{C}$. The OD of supernatant was measured at both $550 \mathrm{~nm}$ and $540 \mathrm{~nm}$, the amount of generated super oxide anion was shown in the formula; increased absorbance at $550 \mathrm{~nm}\left(\Delta \mathrm{A}_{550-540}\right) / 19.1 \times 10^{3} \mathrm{mmol} / \mathrm{ml}$. In order to ensure if we really measured the amount of generated super oxide anion or not, we tried to add super oxide anion dismutase (SOD), famous enzyme for its anti-oxidative effect, into our experimental system after 3, 5 and 10 minutes after the reaction. 
Table 1. In order to ensure if we really measured the amount of generated super oxide anion or not, we tried to add super oxide anion dismutase (SOD), famous enzyme for its anti-oxidative effect, into our experimental system. The reaction was clearly chased by mixing SOD.

\begin{tabular}{ccc}
\hline Group & \multicolumn{2}{c}{ Generated $\mathrm{O}_{2}$} \\
& Before Chasing & After Chasing \\
\hline 3 Minutes & 0.29 & 0.02 \\
5 Minutes & 0.81 & 0.12 \\
10 Minutes & 1.52 & 0.95 \\
20 Minutes & 2.58 & - \\
\hline
\end{tabular}

The reaction mixture was then centrifuged for 10 minutes at $1500 \mathrm{rpm}, 4^{\circ} \mathrm{C}$. The OD of supernatant was measured at both $550 \mathrm{~nm}$ and $540 \mathrm{~nm}$, the amount of generated super oxide anion was shown in the formula; increased absorbance at $550 \mathrm{~nm}\left(\Delta \mathrm{A}_{550-540}\right) / 19.1 \times 10^{3} \mathrm{mmol} / \mathrm{ml}$.

In order to ensure if we really measured the amount of generated super oxide anion or not, we tried to add super oxide anion dismutase (SOD), famous enzyme for its anti-oxidative effect, into our experimental system.

\subsection{The Comparison of Generated Super Oxide Anion between Vin Blank and Vin Rouge}

Three groups of mice were set up by each ten individuals. Each mouse was orally administered $0.5 \mathrm{ml}$ of alcohol-less wine.

The experimental animals were orally administered by each sample for $200 \mathrm{mg} / \mathrm{kg}$ by a stomach tube. The peritoneal excaudate cells were collected 5 days after injection with oyster glycogen. The cell sample consisted with $92 \%$ of macrophages. The collected cells were treated by the method described in the Section 2.5. The amount of generated super oxide anion was calculated in the formula shown in the Section 2.5 (Table 2).

Both groups of mice that administered each wine were responding to antioxidative response. However, there was no difference between the group administered vin rouge and vin blank. Rather vin blank group was tend to more strong anti-oxidative response, but there is no significant difference in both wine group.

Figure 3, three groups of mice were set up by each ten individuals. Each mouse was orally administered 0.5 $\mathrm{ml}$ of alcohol-less wine.

The experimental animals were orally administered by each sample for $200 \mathrm{mg} / \mathrm{kg}$ by a stomach tube. The peritoneal excaudate cell was collected 5 days after injection with oyster glycogen. The cell sample consisted with $92 \%$ of macrophages. The collected cell was treated by the method described in the Section 2.5. The amount of generated super oxide anion was calculated in the formula shown in the Section 2.5 .

\section{Discussion}

Reactive oxygen species released by activated polymorphonuclear leukocyte as an expression of their definitive function are considered to be major source of cytotoxic oxidative stress. Since oxygen free radicals cause DNA damage and this may lead to gene modifications, reactive oxygen might be carcinogenic. Therefore oxidative stress is reported to cause many disorders such as cancer, ischemic heart disease and diabetes [27]-[29].

However, like armed forces reduction treaty, the minimum armed forces are necessary for our environment except germ free environment. Although there are many reports in which the newly found antioxidants were reported and discussed about the molecular mechanism of how oxidative stress damage the human tissue [30]-[34], few experiments have been done in vivo which could reflex more precisely the biological response.

The purpose of this study has been to establish the method which is useful for evaluating the activity of antioxidant ex vivo. As shown above, in our experiment design, the amount of super oxide anion generation decreased significantly after one-week administration of some drugs. The advantage of this method might be what the amount of super oxide anion generation could express clearly in concrete numeral, so it is easy to compare various drugs.

The most interesting in this assay was that the generation of super oxide anion was much more inhibited after 
Table 2. The experimental animals were orally administered by each sample for $200 \mathrm{mg} / \mathrm{kg}$ by a stomach tube. The peritoneal excaudate cells were collected 5 days after injection with oyster glycogen. The cell sample consisted with $92 \%$ of macrophages. The collected cells were treated by the method described in the Section 2.5. The amount of generated super oxide anion was calculated in the formula shown in the Section 2.5. Both group of mice that administered each wine was respond to anti-oxidative response. However, there was no difference between the group administered vin rouge and vin blank. Rather vin blank group was tend to more strong anti-oxidative response, but there is no significant difference in both wine group. The real value of figure was shown in the Table.

\begin{tabular}{cc} 
Group & Generated $\mathrm{O}_{2}$ \\
\hline Control & $3.52 \pm 0.43$ \\
Vin Blanc & $2.25 \pm 0.35^{* * *}$ \\
Vin Rouge & $2.39 \pm 0.56^{* * *}$ \\
\hline
\end{tabular}

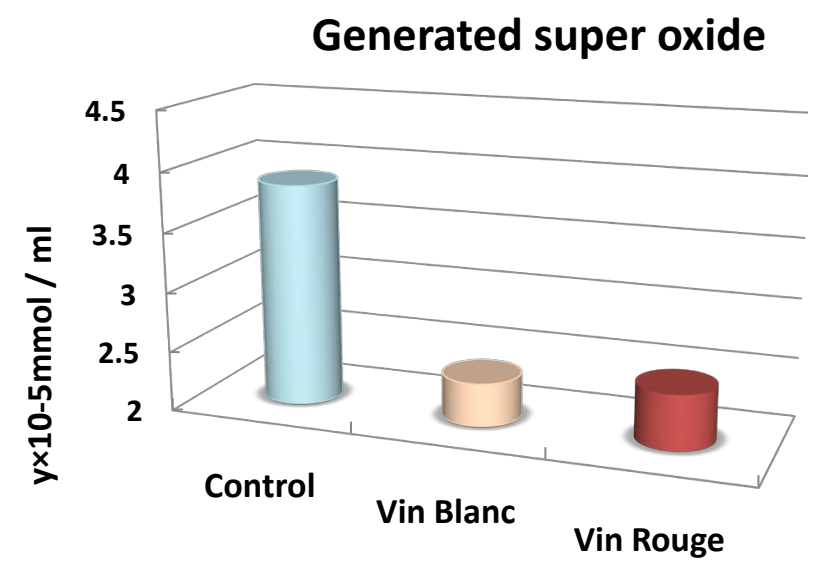

Figure 3. A judging anti-oxidative activity by the macrophages from both groups. Each wine sample was orally administered to mice $(200 \mathrm{mg} / \mathrm{kg}$ ) every day for one week. Then two $\mathrm{ml}$ of $10 \%$ oyster glycogen was injected intraperitonealy about 10 hours before the assay. A sufficient murine peritoneal exudate cell was induced ten hours after the stimulation. Mice were euthanized by cervical dislocation, murine PEC suspension was centrifuged twice for 5 minutes at $1500 \mathrm{rpm}, 4^{\circ} \mathrm{C}$. Then PEC was prepared to $1 \times 10^{6}$ cells $/ \mathrm{ml}$ of HEPES buffer. One hundred $\mu$ cytochrome-C and $10 \mu \mathrm{l}$ of PMA were added to the cell suspension and this was incubated for 20 minutes at $37^{\circ} \mathrm{C}$. The reaction mixture was then centrifuged for 10 minutes at 1500 $\mathrm{rpm}, 4^{\circ} \mathrm{C}$. The $\mathrm{OD}$ of supernatant was measured at both $550 \mathrm{~nm}$ and $540 \mathrm{~nm}$, the amount of generated super oxide anion was shown in the formula; increased absorbance at $550 \mathrm{~nm}\left(\Delta \mathrm{A}_{550-540}\right) / 19.1 \times 10^{3} \mathrm{mmol} / \mathrm{ml}$.

white wine administration than red wine. It is widely accepted that polyphenol contained in red wine has great anti-oxidative effects. However, as we demonstrated in this report, white wine has more efficient anti-oxidative activity. The confusion that red wine prefers anti-oxidative effects was pulled out by the results from in vitro system. We would like to stress the anti-oxidative test should first be evaluated by the in vivo system employing the cells work at the front of battle line of defense by phagocytic cell. The phagocytic cells have much oxidative enzyme against foreign microorganisms. Moreover this confusion biased from the colored substance such as anthocyanin combined directory with the color of red wine. Thus, we would like to recommend testing the anti-oxidative activity, if possible, in vivo in future.

In this report, the method how to measure the amount of super oxide anion generation when both wines were administered in vivo was shown. Using this method, it would be easy to test the anti-oxidative activity of any drugs and supplements for human subject. This will bring the difference of oxidative activity in monocyte in human blood, as qualitative aspect. The anti-oxidative stress should be regulated as armed forces reduction treaty, but not dissemination of armed forces [35]-[39].

\section{References}

[1] Gorantla, S., Dou, H., Boska, M., Destache, C.J., Nelson, J., Poluektova, L., Rabinow, B.E., Gendelman, H.E. and Mosley, R.L. (2006) Quantitative Magnetic Resonance and SPECT Imaging for Macrophage Tissue Migration and 
Nanoformulated Drug Delivery. Journal of Leukocyte Biology, 80, 1165-1174. http://dx.doi.org/10.1189/jlb.0206110

[2] Stoika, R.S., Lutsik, M.D., Barska, M.L., Tsyrulnyk, A.A. and Kashchak, N.I. (2002) In Vitro Studies of Activation of Phagocytic Cells by Bioactive Peptides. Journal of Physiology and Pharmacology, 53, 675-688.

[3] Elbim, C., Pillet, S., Prevost, M.H., Preira, A., Girard, P.M., Rogine, N., Hakim, J., Israel, N. and Gougerot-Pocidalo, M.A. (2001) The Role of Phagocytes in HIV-Related Oxidative Stress. Journal of Clinical Virology, 20, 99-109. http://dx.doi.org/10.1016/S1386-6532(00)00133-5

[4] Speer, C.P., Gahr, M. and Pabst, M.J. (1986) Phagocytosis-Associated Oxidative Metabolism in Human Milk Macrophages. Acta Paediatrica, 75, 444-451. http://dx.doi.org/10.1111/j.1651-2227.1986.tb10228.x

[5] Yamaguchi, N., Kawada, N., Jia, X.F., Okamoto, K., Okuzumi, K., Chen, R. and Takahashi, T. (2014) Overall Estimation of Anti-Oxidant Activity by Mammal Macrophage. Open Journal of Rheumatology and Autoimmune Diseases, 4, $13-21$.

[6] Waitzberg, D.L., Bellinati-Pires, R., Salgado, M.M., Hypolito, I.P., Colleto, G.M., Yagi, O., Yamamuro, E.M., Gama-Rodrigues, J. and Pinotti, H.W. (1997) Effect of Total Parenteral Nutrition with Different Lipid Emulsions of Human Monocyte and Neutrophil Functions. Nutrition, 13, 128-132. http://dx.doi.org/10.1016/S0899-9007(96)00386-3

[7] Kaplan, S.S., Basford, R.E., Jeong, M.H. and Simmons, R.L. (1996) Biomaterial-Neutrophil Interactions: Dysregulation of Oxidative Functions of Fresh Neutrophils Induced by Prior Neutrophil-Biomaterial Interaction. Journal of Biomedical Materials Research, 30, 67-75.

http://dx.doi.org/10.1002/(SICI)1097-4636(199601)30:1<67::AID-JBM9>3.0.CO;2-P

[8] Cohen, M.S., Britigan, B.E., Chai, Y.S., Pou, S., Roeder, T.L. and Rosen, G.M. (1991) Phagocyte-Derived Free Radicals Stimulated by Ingestion of Iron-Rich Staphylococcus Aureus: A Spin-Trapping Study. The Journal of Infectious Diseases, 163, 819-824. http://dx.doi.org/10.1093/infdis/163.4.819

[9] Mege, J.L., Martin, C., Saux, P., Charrel, J., Mallet, M.N. and Bongrand, P. (1989) Phagocyte-Pathogen in the Infected Host. Critical Care Medicine, 17, 1247-1253.

[10] Kasai, S. and Yamaguchi, N.(2004) IL-12 Production Induced by Agaricus Blazei Fraction H(ABH) Involves Toll-like Receptor (TLR), eCAM, 1, 259-267.

[11] Root, R.K., Rosenthal, A.S. and Balestra, D.J. (1972) Abnormal Bactericidal, Metabolic, and Lysosomal Functions of Chediak-Higashi Syndrome Leukocytes. Journal of Clinical Investigation, 51, 649-665. http://dx.doi.org/10.1172/JCI106854

[12] Ignarro, L.J. and Colombo, C. (1973) Enzyme Release from Polymorphonuclear Leukocyte Lysosomes: Regulation by Autonomic Drugs and Cyclic Nucleotides. Science, 180, 1181-1183. http://dx.doi.org/10.1126/science.180.4091.1181

[13] Dulis, B.H. and Wilson, I.B. (1980) The $\beta$-Adrenergic Receptor of Live Human Polymorphonuclear Leukocytes. Journal of Biological Chemistry, 255, 1043-1048.

[14] Nakahata, H., Tsujino, M., Hirai, Y., Kumasaka, Y., Nakamura, T., Onuma, T., Kudo, M., Takebe, K. and Kudo, H. (1990) Clinical Study of Superoxide Disumutase (SOD) in NIDDM-Serum and Polymorphonuclear Leukocyte (PMN) SOD Activity by Nitrite Method. Journal of the Japan Diabetes Society, 33, 965-971.

[15] Coletta, A., Berto, S., Crupi, P., Cravero, M.C., Tamborra, P. and Antonacci, D. (2014) Effect of Viticulture Practices on Concentration of Polyphenolic Compounds and Total Antioxidant Capacity of Southern Italy Red Wines. Food Chemistry, 152, 467-474. http://dx.doi.org/10.1016/j.foodchem.2013.11.142

[16] Pinzani, P., Petruzzi, E., Magnolfi, S.U., Malentacchi, F., Siena, G.D., Petruzzi, I., Motta, M., Malaguarnera, M., Marchionni, N. and Pazzagli, M. (2010) Red or White Wine Assumption and Serum Antioxidant Capacity. Archives of Gerontology and Geriatrics, 51, e72-e74. http://dx.doi.org/10.1016/j.archger.2009.12.007

[17] Iqbal, M., Sharma, S.D., Okazaki, Y., Fujisawa, M. and Okada, S. (2003) Dietary Supplementation of Curcumin Enhances Antioxidant and Phase II Metabolizing Enzymes in ddY Male Mice: Possible Role in Protection against Chemical Carcinogenesis and Toxicity. Pharmacology and Toxicology, 92, 33-38.

[18] Campanella, L., Bonanni, A., Finotti, E. and Tomassetti, M. (2004) Biosensors for Determination of Total and Natural Antioxidant Capacity of Red and White Wines: Comparison with Other Spectrophotometric and Fluorimetric Methods. Biosensors and Bioelectronics, 19, 641-651. http://dx.doi.org/10.1016/S0956-5663(03)00276-8

[19] Hosu, A., Cristea, V.M. and Cimpoiu, C. (2014) Analysis of Total Phenolic, Flavonoids, Anthocyanins and Tannins Content in Romanian Red Wines: Prediction of Antioxidant Activities and Classification of Wines Using Artificial Neural Networks. Food Chemistry, 150, 113-118. http://dx.doi.org/10.1016/j.foodchem.2013.10.153

[20] Wei, Y.H. and Lee, H.C. (2002) Oxidative Stress, Mitochondrial DNA Mutation, and Impairment of Antioxidant Enzymes in Aging. Experimental Biology and Medicine (Maywood), 227, 671-682.

[21] Sanz, N., Diez-Fernández, C., Andrés, D. and Cascales, M. (2002) Hepatotoxicity and Aging: Endogenous Antioxidant 
Systems in Hepatocytes from 2-, 6-, 12-, 18- and 30-Month-Old Rats Following a Necrogenic Dose of Thioacetamide. Biochimica et Biophysica Acta (BBA), Molecular Basis of Disease, 1587, 12-20. http://dx.doi.org/10.1016/S0925-4439(02)00048-0

[22] Diamond, J., Skaggs, J. and Manaligod, J.M. (2002) Free-Radical Damage: A Possible Mechanism of Laryngeal Aging. Ear, Nose, \& Throat Journal, 81, 531-533.

[23] Melov, S. (2002) Animal Models of Oxidative Stress, Aging, and Therapeutic Antioxidant Interventions. The International Journal of Biochemistry \& Cell Biology, 34, 1395-1400. http://dx.doi.org/10.1016/S1357-2725(02)00086-9

[24] Rani, P.J.A. and Panneerselvam, C. (2001) Carnitine as a Free Radical Scavenger in Aging. Experimental Gerontology, 36, 1713-1726. http://dx.doi.org/10.1016/S0531-5565(01)00116-4

[25] Kasapoglu, M. and Özben, T. (2001) Alterations of Antioxidant Enzymes and Oxidative Stress Markers in Aging. Experimental Gerontology, 36, 209-220. http://dx.doi.org/10.1016/S0531-5565(00)00198-4

[26] Yamaguchi, N., Kawada, N., Jia, X., Okamoto, K., Okuzumi, K., Chen, R. and Takahashi, T. (2014) Takahashi Overall Estimation of Anti-Oxidant Activity by Mammal Macrophage. Open Journal of Rheumatology and Autoimmune Diseases, 4,13-21,. http://dx.doi.org/10.4236/ojra.2014.41002

[27] Edsmyr, F. (1982) Super Oxide Anion Dismutase Efficacy in Ameliorating Side Effects of Radiation Therapy "Pathology of Oxygen”. In: Autor, A.M., Ed., Academic Press, New York, 315-326.

[28] Johansson, M.H., Deinum, J., Marklund, S.L. and Sjoquist, P.O. (1990) Recombinant Human Extra-Celluar Super Oxide Anion Dismutase Reduces Concentration of Oxygen Free Redicals in the Reperfusedret Heart. Cardiouas, 24, 500-503.

[29] Venugopal, S.K., Devaraj, S., Yang, T. and Jialal, L. (2002) $\alpha$-Tocopherol Decreases Superoxide Anion Release in Human Monocytes under Hyperglycemic Conditions via Inhibition of Protein Kinase C- $\alpha$. Diabetes, 51, 3049-3054. http://dx.doi.org/10.2337/diabetes.51.10.3049

[30] Nayak, D.U., Karmen, C., Frishman, W.H. and Vakili, B.A. (2001) Antioxidant Vitamins and Enzymatic and Synthetic Oxygen-Derived Free Radical Scavengers in the Prevention and Treatment of Cardiovascular Disease. Heart Disease, 3, 28-45.

[31] Miyachi, Y. (1993) Skin Diseases Associated with Oxidative Injury. In: Fuchs, J. and Packer, L., Eds., Oxidative Stress in Dermatology, Marcel Dekker, New York, 323-331.

[32] De Beer, D., Joubert, E., Gelderblom, W.C. and Manley, M. (2003) Antioxidant Activity of South African Red and White Cultivar Wines: Free Radical Scavenging. Journal of Agricultural and Food Chemistry, 51, 902-909. http://dx.doi.org/10.1021/jf0260110

[33] Lee, S.E., Ju, E.M. and Kim, J.H. (2001) Free Radical Scavenging and Antioxidant Enzyme Fortifying Activities of Extracts from Smilax China Root. Experimental \& Molecular Medicine, 33, 263-268. http://dx.doi.org/10.1038/emm.2001.43

[34] Joshi, R., Adhikari, S., Patro, B.S., Chattopadhyay, S. and Mukherjee, T. (2001) Free Radical Scavenging Behavior of Folic Acid: Evidence for Possible Antioxidant Activity. Free Radical Biology and Medicine, 30, 1390-1399. http://dx.doi.org/10.1016/S0891-5849(01)00543-3

[35] Lin, C.C., Hsu, Y.F. and Lin, T.C. (2001) Antioxidant and Free Radical Scavenging Effects of the Tannins of Terminalia catappa L. Anticancer Research, 21, 237-243.

[36] Abo, T. and Kumagai, T. (1978) Studies of Surface Immunoglobulins on Human B Lymphocytes. III. Physiological Variations of Sig ${ }^{+}$Cells in Peripheral Blood. Clinical Experimental Immunology, 33, 441-452.

[37] Sanders, V.M., Baker, R.A., Ramer-Quinn, D.S., Kasprowicz, D.J., Fuchs, B.A. and Street, N.E. (1997) Differential Expression of the $\beta_{2}$-Adrenaergic Receptor by Th1 and Th2 Clones. Journal of Immunology, 158, 4200-4210.

[38] Abo, T., Kawate, T., Itoh, K. and Kumagai, K. (1981) Studies on the Bioperiodicity of the Immune Response. 1. Circadian Rhythms of Human T, B and K Cell Traffic in the Peripheral Blood. Journal of Immunology, 126, 1360-1363.

[39] Kitada, Y., Okamoto, K., Takei, T., Jia, X.F., Chen, R., Yamaguchi, N., Tsubokawa, M., Wu, W.H., Murayama, T. and Kawakita, K. (2013) Hot Spring Hydro Therapy Regulate Peripheral Leukocyte Together with Emotional Hormone and Receptor Positive Lymphocytes According to Each Constitution/Condition. Open Journal of Rheumatology and Autoimmune Diseases, 3, 140-153. 
Scientific Research Publishing (SCIRP) is one of the largest Open Access journal publishers. It is currently publishing more than 200 open access, online, peer-reviewed journals covering a wide range of academic disciplines. SCIRP serves the worldwide academic communities and contributes to the progress and application of science with its publication.

Other selected journals from SCIRP are listed as below. Submit your manuscript to us via either submit@scirp.org or Online Submission Portal.
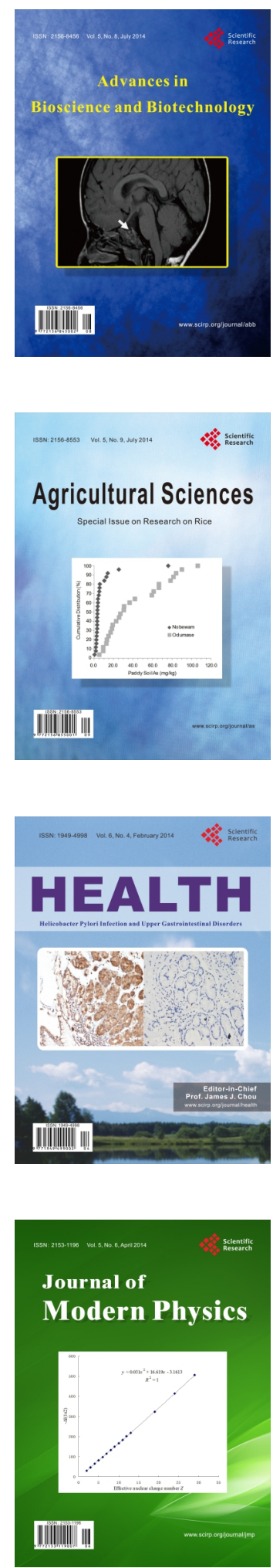
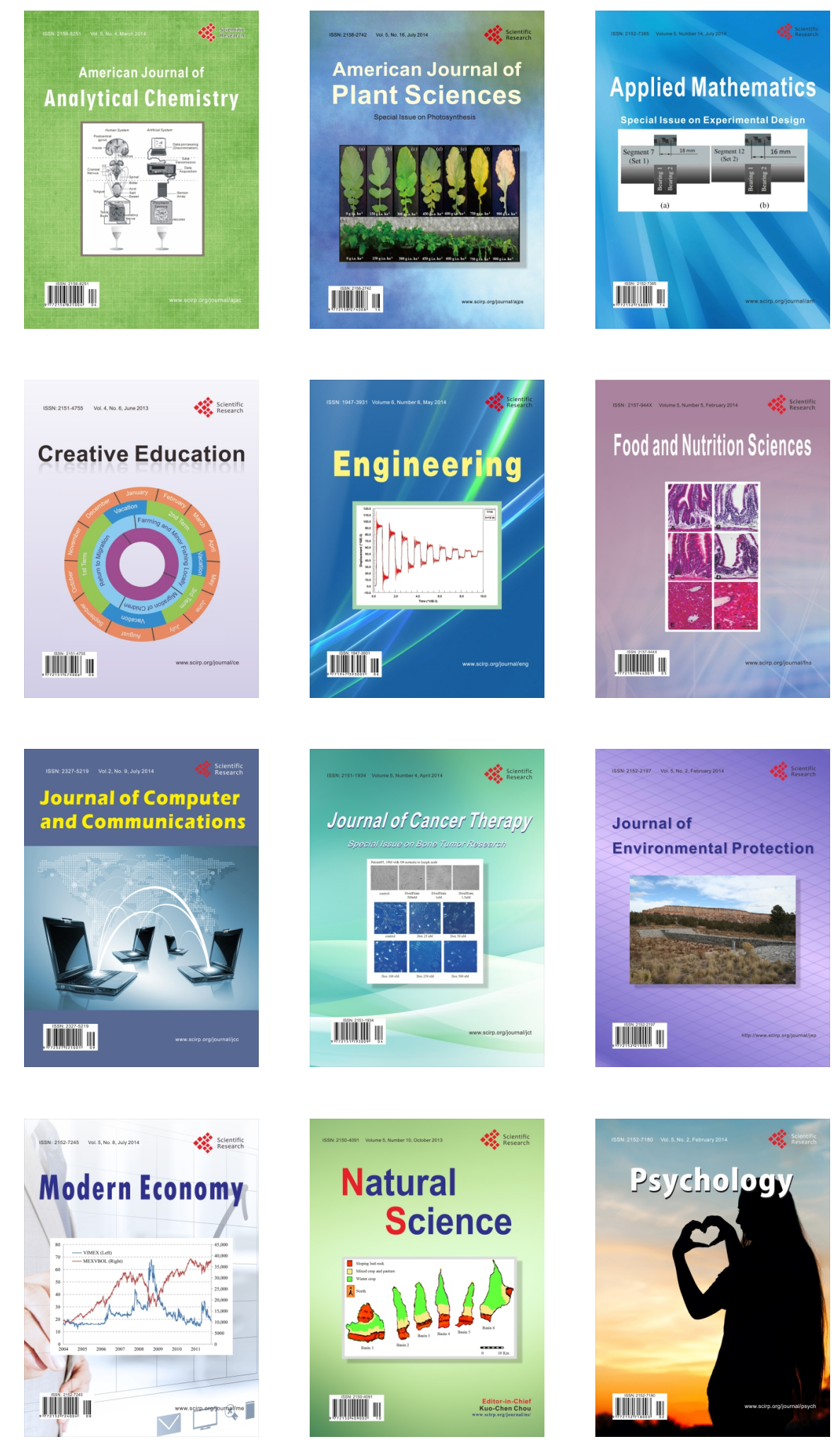